\title{
Retraction
}

\section{Retracted: The Healing of Oxidative Injuries with Trehalose in UVB-Irradiated Rabbit Corneas}

\author{
Oxidative Medicine and Cellular Longevity \\ Received 20 November 2020; Accepted 20 November 2020; Published 21 December 2020 \\ Copyright (C) 2020 Oxidative Medicine and Cellular Longevity. This is an open access article distributed under the Creative \\ Commons Attribution License, which permits unrestricted use, distribution, and reproduction in any medium, provided the \\ original work is properly cited.
}

Oxidative Medicine and Cellular Longevity has retracted the article titled "The Healing of Oxidative Injuries with Trehalose in UVB-Irradiated Rabbit Corneas" [1] due to concerns with the figures. We were contacted by an author of the article who identified that Figure $4 \mathrm{c}$ in [1] is duplicated with $6 \mathrm{a}$ in [2], despite different experimental conditions being described. Figure $6 c$ in [1] is also duplicated with Figure $5 \mathrm{~d}$ in [2] despite different experimental conditions being described. The first author responded with an explanation and revised figures, but these did not satisfactorily address the concerns of the editorial board. The article is therefore being retracted due to concerns regarding the reliability of the data. The authors Sarka Kubinova and Céline Olmiere agree to the retraction of the article, however, all other authors do not agree.

\section{References}

[1] C. Cejka, J. Kossl, B. Hermankova et al., "The Healing of Oxidative Injuries with Trehalose in UVB-Irradiated Rabbit Corneas," Oxidative Medicine and Cellular Longevity, vol. 2019, Article ID 1857086, 10 pages, 2019.

[2] V. Holan, P. Trosan, C. Cejka et al., "A Comparative Study of the Therapeutic Potential of Mesenchymal Stem Cells and Limbal Epithelial Stem Cells for Ocular Surface Reconstruction," Stem Cells Translational Medicine, vol. 4, no. 9, pp. 10521063, 2015. 